\title{
A new purple sulfur bacterium from saline littoral sediments, Thiorhodovibrio winogradskyi gen. nov. and sp. nov.
}

\author{
Jörg Overmann ${ }^{1}$, Ulrich Fischer ${ }^{2}$, and Norbert Pfennig ${ }^{1}$ \\ 1 Fakultät für Biologie, Universität Konstanz, Postfach 5560, W-7750 Konstanz, Federal Republic of Germany \\ 2 Fachbereich Biologie, AG Geomikrobiologie, Universität Oldenburg, Postfach 2503, W-2900 Oldenburg, Federal Republik of Germany
}

Received September 6, 1991/Accepted November 14, 1991

\begin{abstract}
Two strains of a new purple sulfur bacterium were isolated in pure culture from the littoral sediment of a saline lake (Mahoney Lake, Canada) and a marine microbial mat from the North Sea island of Mellum, respectively. Single cells were vibrioid-to spirilloid-shaped and motile by means of single polar flagella. Intracellular photosynthetic membranes were of the vesicular type. As photosynthetic pigments, bacteriochlorophyll a and the carotenoids lycopene, rhodopin, anhydrorhodovibrin, rhodovibrin and spirilloxanthin were present.

Hydrogen sulfide and elemental sulfur were used under anoxic conditions for phototrophic growth. In addition one strain (06511) used thiosulfate. Carbon dioxide, acetate and pyruvate were utilized by both strains as carbon sources. Depending on the strain propionate, succinate, fumarate, malate, tartrate, malonate, glycerol or peptone may additionally serve as carbon sources in the light. Optimum growth rates were obtained at $\mathrm{pH}$ $7.2,33^{\circ} \mathrm{C}, 50 \mu \mathrm{mol} \mathrm{m} \mathrm{m}^{-2} \mathrm{~s}^{-1}$ intensity of daylight fluorescent tubes and a salinity of $2.2-3.2 \% \mathrm{NaCl}$. During growth on sulfide, up to ten small sulfur globules were formed inside the cells. The strains grew microaerophilic in the dark and exhibited high specific respiration rates. No vitamins were required for growth. The DNA base composition was $61.0-62.4 \mathrm{~mol} \% \mathrm{G}+\mathrm{C}$.

The newly isolated bacterium belongs to the family Chromatiaceae and is described as a member of a new genus and species, Thiorhodovibrio winogradskyi gen. nov. and sp. nov. with the type strain SSP1, DSM No. 6702 .
\end{abstract}

Key words: Chromatiaceae - Purple sulfur bacteria Thiorhodovibrio - Saline lakes - Littoral sediments Marine microbial mats - Bacteriochlorophyll a Spirilloxanthin - Sulfur

Purple sulfur bacteria thrive planktonically in anoxic water layers of stratified lakes and colonize anoxic marine or freshwater sediments (Takahashi and Ichimura 1968;

Offprint requests to: J. Overmann
Parkin and Brock 1980; Nicholson et al. 1987; Pfennig 1989; van Gemerden et al. 1989).

Among Chromatiaceae, various small Chromatium species such as C. vinosum, $C$. violascens, C. gracile, C. minutissimum, C.minus, as well as Thiocystis violacea, Thiocapsa roseopersicina, and Amoebobacter roseus are regularly found in sediments containing hydrogen sulfide and reached by light (Trüper 1980; Nicholson et al. 1987).

During recent investigation of the meromictic Mahoney Lake (British Columbia, Canada) (Overmann et al. 1991), the littoral sediments on the south eastern shore of the lake were found to bear a faint pinkish color. Light microscopic examination of sediment samples revealed the presence of cells resembling Amoebobacter purpureus, Chromatium sp., and an unknown vibrioidshaped type of cells containing small intracellular sulfur globules (Fig. 1). These cells exhibited considerably different morphology compared to all known species of the Chromatiaceae. Cells of similar morphology were detected in a laminated microbial mat ("Farbstreifensandwatt") on the shore of the North Sea island Mellum.

From samples of both habitats, representative strains were isolated in pure culture. On the basis of their cytological, physiological and biochemical properties, the newly isolated strains are considered as members of a new genus and species Thiorhodovibrio winogradskyi.

\section{Materials and methods}

\section{Source of organisms}

Mahoney Lake is a small meromictic lake located near Penticton in the south central region of British Columbia (Canada). Samples were obtained from 0 to $6 \mathrm{~cm}$ depth of the littoral sediments on the South Eastern shore.

The bacterium was also detected in samples from laminated microbial mats on the shore of the North Sea island of Mellum (FRG) and in microbial mats of the Great Sippewissett Salt Marsh, Mass., USA.

\section{Isolation and cultivation}

Pure cultures were obtained by repeated deep agar dilution series (Pfennig 1978). The basal medium used for isolation and further 


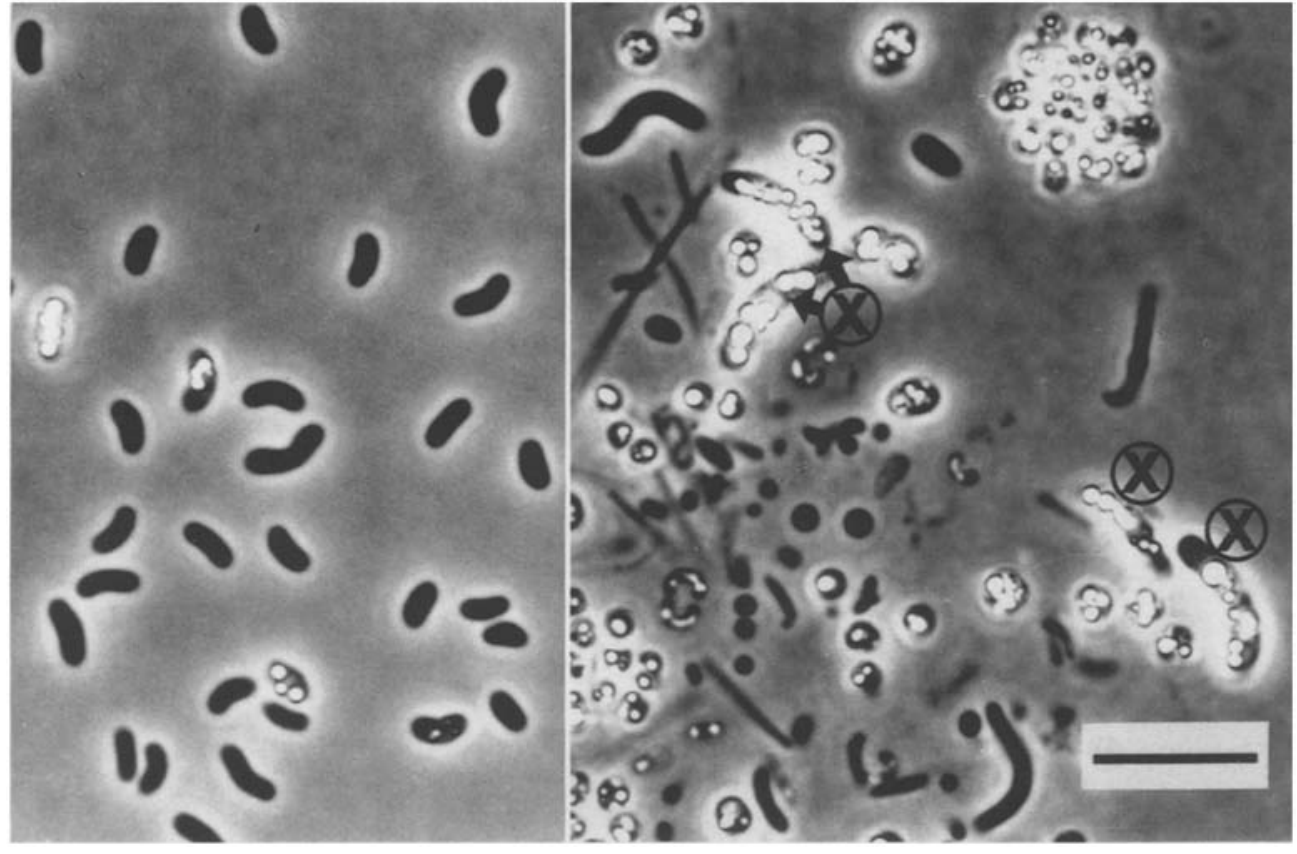

Fig. 1. Right. Phase contrast photomicrograph of a sediment sample obtained from South Eastern shore of Mahoney Lake (British Columbia, Canada). $(\otimes)=$ vibrioid-shaped bacteria containing small intracellular sulfur globules. Left. Pure culture of strain SSP1 grown at $28^{\circ} \mathrm{C}$ and $100 \mu \mathrm{mol} \mathrm{m} \mathrm{m}^{-2} \mathrm{~s}^{-1}$ tungsten light (phase contrast). $B a r=10 \mu \mathrm{m}$

cultivation of the organisms contained per liter distilled water: $\mathrm{KH}_{2} \mathrm{PO}_{4}, 0.25 \mathrm{~g} ; \mathrm{NH}_{4} \mathrm{Cl} 0.34 \mathrm{~g} ; \mathrm{KCl}, 0.34 \mathrm{~g} ; \mathrm{NaCl} 20.0 \mathrm{~g}$; $\mathrm{MgSO}_{4} \cdot 7 \mathrm{H}_{2} \mathrm{O}, 2.80 \mathrm{~g} ; \mathrm{CaCl}_{2} \cdot 2 \mathrm{H}_{2} \mathrm{O}, 0.25 \mathrm{~g} ; \mathrm{NaHCO}_{3}, 1.50 \mathrm{~g}$; $\mathrm{Na}_{2} \cdot 9 \mathrm{H}_{2} \mathrm{O}, 0.60 \mathrm{~g}$; vitamin $\mathrm{B}_{12}, 0.02 \mathrm{mg}$; trace element solution SL $12,1 \mathrm{ml}$. The new trace element solution SL 12 is an improved modification of SL 8 (Pfennig and Trüper 1981) and contains the following components in $\mathrm{mg}$ per liter of distilled water: EDTA- $\mathrm{Na}_{2} \cdot 2 \mathrm{H}_{2} \mathrm{O}, 3000, \mathrm{FeSO}_{4} \cdot 7 \mathrm{H}_{2} \mathrm{O}, 1100 ; \mathrm{H}_{3} \mathrm{BO}_{3}, 300$; $\mathrm{CoCl}_{2} \cdot 6 \mathrm{H}_{2} \mathrm{O}, 190 ; \mathrm{MnCl}_{2} \cdot 4 \mathrm{H}_{2} \mathrm{O}, 50 ; \mathrm{ZnCl}_{2}, 42 ; \mathrm{NiCl}_{2} \cdot 6 \mathrm{H}_{2} \mathrm{O}$, 24; $\mathrm{NaMoO}_{4} \cdot 2 \mathrm{H}_{2} \mathrm{O}, 18 ; \mathrm{CuCl}_{2} \cdot 2 \mathrm{H}_{2} \mathrm{O}, 2$. The EDTA-Na dissolved first, followed by the other components. The basal medium was sterilized, the $\mathrm{pH}$ adjusted to $7.2-7.3$ and the medium aseptically distributed into culture vessels as described by Pfennig and Trüper (1981).

Purity of cultures was checked microscopically and by growth tests in Difco AC medium.

Cultures were grown photosynthetically in $50-\mathrm{ml}$ screw cap bottles at $100 \mu \mathrm{mol} \mathrm{m}{ }^{-2} \mathrm{~s}^{-1}$ light intensity of a tungsten lamp and a temperature of $20^{\circ} \mathrm{C}$ (standard conditions). Repeated addition of neutralized sulfide solution (Siefert and Pfennig 1984) was used to obtain high cell yields. Stock cultures were stored at $4{ }^{\circ} \mathrm{C}$ in the dark.

Growth experiments were performed in $100-\mathrm{ml}$ screw cap bottles following the increase of cell numbers by counting subsamples after fixation with formaldehyde $(0.4 \mathrm{vol} \%)$ in a Helber (depth $0.02 \mathrm{~mm}$ ) or Neubauer (depth $0.1 \mathrm{~mm}$ ) counting chamber.

Chemotrophic growth in the dark was tested in continuous culture experiments according to de Wit and van Gemerden (1989). Hydrogen sulfide $(1 \mathrm{mM})$ was added as electron donor, hydrogen carbonate and acetate $(3 \mathrm{mM})$ served as carbon sources. During the experiments the oxygen partial pressure was reduced to $1 \%$.

\section{Analytical procedures}

Pigments. Absorption spectra were recorded with a Shimadzu UV 300 spectrophotometer equipped with an end-on photomultiplier. Prior to measurements, the cells were passed through a French press (Aminco, Silver Spring, Md, USA; pressure $=6.7 \cdot 10^{6} \mathrm{~Pa}$ ). Changes in the position of absorption maxima as compared to untreated samples were not observed.

Bacteriochlorophylls were extracted overnight at $4{ }^{\circ} \mathrm{C}$ with acetone. A specific extinction coefficient of $92.3 \mathrm{ml} \cdot \mathrm{mg}^{-1} \cdot \mathrm{cm}^{-1}$ was used (Steenbergen and Korthals 1982). Protein was determined according to Hartree (1972). For calibration standard solutions of bovine serum albumin were used.

For determination of carotenoid pigments, freeze-dried cells were first extracted for $20 \mathrm{~min}$ with methanol (at $60^{\circ} \mathrm{C}$, containing $6 \%$ $\mathrm{v} / \mathrm{v} \mathrm{KOH})$ and afterwards twice with acetone $(10 \mathrm{~min}$, room temperature). Extracts were combined in a separatory funnel and an equal volume of diethyl ether/petroleum ether $(1 / 10, \mathrm{v} / \mathrm{v}$; boiling range of petroleum ether $35^{\circ} \mathrm{C}-80^{\circ} \mathrm{C}$ ) was added. Carotenoids were transferred to the ether phase by adding distilled water. The methanol-water phase was discarded. After evaporation of the ether phase, carotenoids were dissolved in $1 \mathrm{ml}$ acetone and analysed by HPLC (Perkin-Elmer, Uberlingen, Germany; column: Spherisorb ODS-1, $5 \mu \mathrm{m}$; eluent acetonitrile/methanol/isopropanol 85/10/5 at a flow rate of $1 \mathrm{ml} \cdot \mathrm{min}^{-1}$; photodiode array detector Waters 994 , Waters, Eschborn, FRG). For identification of carotenoids, extracts of reference strains with known carotenoid composition (Schmidt 1978) were analysed in parallel. Carotenoid concentrations were calculated employing the extinction coefficients reported by Goodwin (1980).

Electron microscopy. Negative staining preparations were performed according to Cole and Popkin (1981) using a 5\% solution of uranyl acetate (pH 5) for staining.

For ultrathin sectioning the cells were fixed in $6 \%$ glutaraldehyde in $0.1 \mathrm{M}$ potassium phosphate buffer, $\mathrm{pH} 7.2$. Post fixation was done in $2 \% \mathrm{OsO}_{4}$. Subsequently the cells were embedded in Epon and staining was performed following the method of Reynolds (1963). Electron micrographs were taken with a Zeiss EM 109 electron microscope (Zeiss, Oberkochen, FRG).

For scanning electron microscopy the cells were fixed in $4 \%$ glutaraldehyde and dehydrated through a graded series of waterethanol mixtures. Cells were dried following the method of critical point drying (Horridge and Tamm 1969) and subsequently coated with gold. Scanning electron micrographs were taken with a Stereoscan 180 (Cambridge Instruments, Cambridge UK).

The mol\% guanine plus cytosine of the DNA was determined by Dr. Jahnke, DSM Braunschweig, FRG, using HPLC according to Meshbah et al. (1989).

Oxygen uptake rates were measured as described by Kämpf and Pfennig (1980) using a polarographic oxygen electrode of the Clark-type (Yellow Springs Instruments, Ohio, USA; model 53). Washed cells were resuspended in $50 \mathrm{mM}$ potassium phosphate buffer ( $\mathrm{pH} 7.4$ ) to a final concentration of $100-300 \mu \mathrm{g}$ protein $\cdot \mathrm{ml}^{-1}$. Measurements were carried out at $30^{\circ} \mathrm{C}$ 


\section{Results}

\section{Natural habitat}

The surface of the Mahoney Lake sediment colonized by purple sulfur bacteria is exposed to atmospheric concentrations of oxygen and full sunlight. The mean concentration of bacteriochlorophyll $a$ in the sediment between depths of 0 and $6 \mathrm{~cm}$ was $4.5 \mu \mathrm{g} \cdot \mathrm{cm}^{-3}$. The integrated amount over this depth was $262 \mathrm{mg}$ bacteriochlorophyll $a \cdot \mathrm{m}^{-2}$.

\section{Isolation}

While several bacterial strains of the new morphological type could be readily isolated from deep agar dilution series directly inoculated with microbial mat samples of Mellum, such a direct isolation was not possible from Mahoney Lake sediment samples. Therefore a selective enrichment procedure was used prior to isolation in deep agar dilution series. Growth medium was inoculated with sediment samples and incubated at $28^{\circ} \mathrm{C}$ behind an infrared light filter (Göttinger Farbfilter $840 \mathrm{E}, 50 \%$ transmission at $840 \mathrm{~nm}$, light source: tungsten light, light intensity $100 \mu \mathrm{mol} \mathrm{m}^{-2} \mathrm{~s}^{-1}$ ). This reproducibly yielded enrichment cultures dominated by the new type of bacterium.

Pinkish lense-shaped colonies of the new phototrophic sulfur bacterium developed only in deep agar dilution series if low agar concentrations were used $(0.6 \%$ instead of $1 \%$ ).

Two strains, one isolated from the Mahoney Lake sediment (strain SSP1, Fig. 1) and another from the laminated microbial mat of Mellum (strain 06511, Fig. 2), were chosen for further characterization.

\section{Morphology and fine structure}

Individual cells of both strains SSP1 and 06511 were motile by means of a single polar flagellum (Fig. 3). Cells

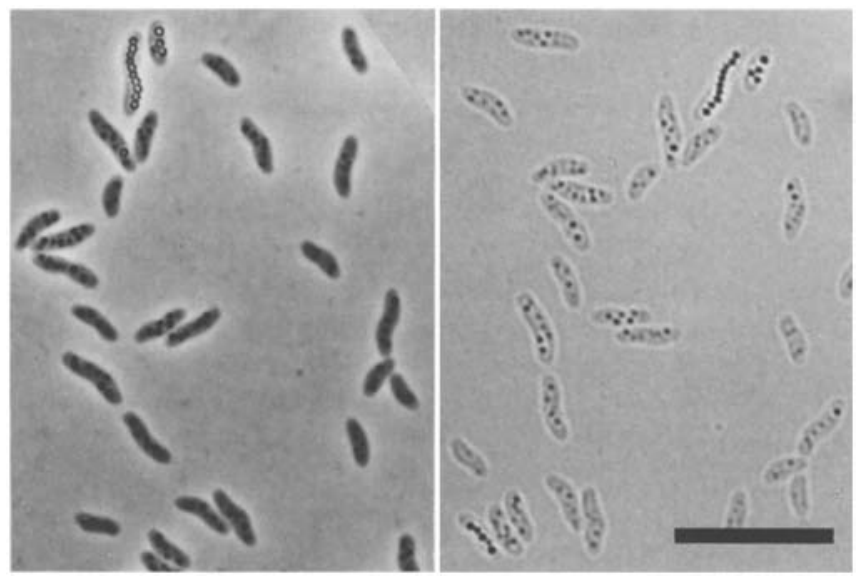

Fig. 2. Phase contrast (left) and bright field (right) photomicrograph of pure cultures of strain 06511. Cells contain up to ten intracellular sulfur globules. Bar $=10 \mu \mathrm{m}$

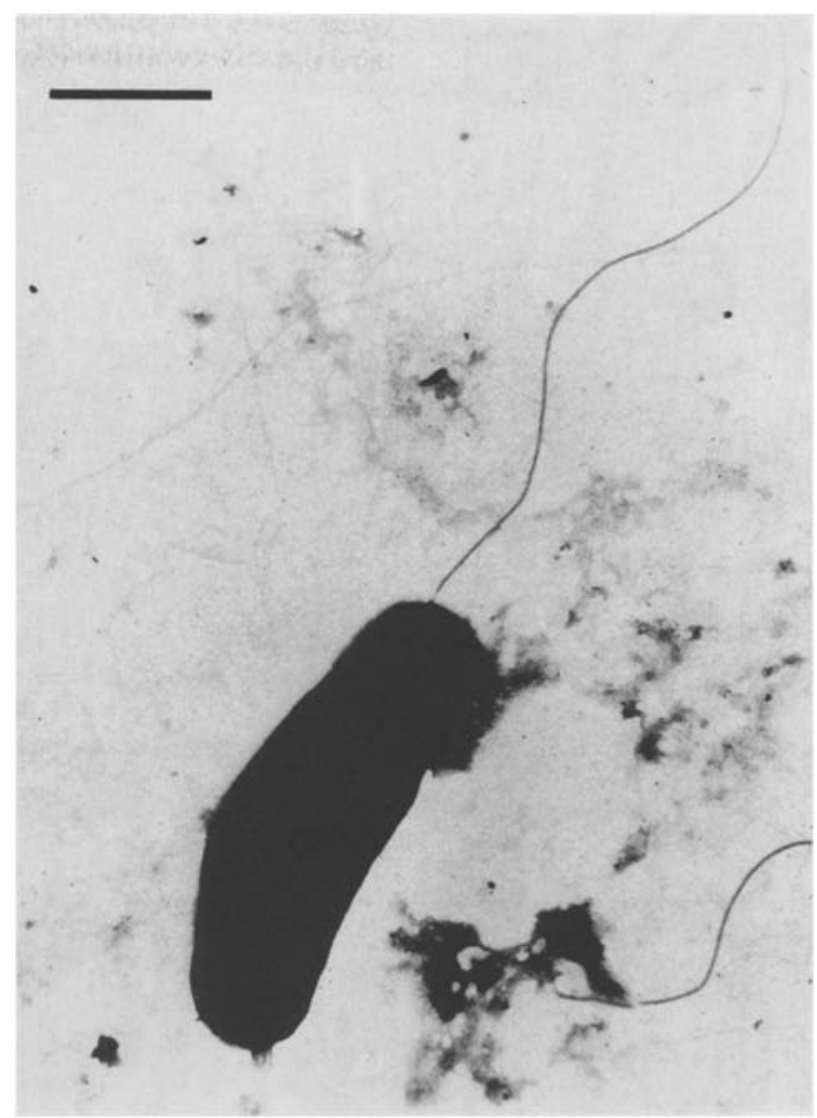

Fig. 3. Negatively stained cell of strain SSP1 showing monopolar inserted flagellum. Bar $=1 \mu \mathrm{m}$

of strain SSP1 were $3.3 \pm 0.7 \mu \mathrm{m}$ long and $1.4 \pm 0.2 \mu \mathrm{m}$ wide, those of 06511 were $3.2 \pm 0.7 \mu \mathrm{m}$ long and 0.8 $\pm 0.1 \mu \mathrm{m}$ wide (Table 1 ). While most cells of strain SSP1 were vibrio-shaped, those of strain 06511 had a slightly more spirilloid morphology.

During phototrophic growth with sulfide, up to ten small sulfur globules per cell appeared in the cytoplasm. Electron microscopic examination of thin sections of both strains revealed an intracellular membrane system of the vesicular type (Fig. 4).

\section{Photosynthetic pigments}

Densely grown cultures were pink to light pinkish-purple in color. The in vivo absorption spectra of both strains were nearly identical (deviation in position of absorption peaks: $1-2 \mathrm{~nm}$ ) and revealed maxima at $867,794,590$, 510,483 and $370 \mathrm{~nm}$ (Fig. 5). Absorption peaks at 867 , 794,590 and $370 \mathrm{~nm}$ can be attributed to the presence of bacteriochlorophyll $a$. In acetone extracts, only one absorption maximum at $770 \mathrm{~nm}$ was detected in the long wavelength region thus confirming that bacteriochlorophyll $a$ is the only bacteriochlorophyll present in both strains.

The shoulder at $510 \mathrm{~nm}$ is due to light absorption by carotenoids. Five carotenoids of the spirilloxanthin series, lycopene, rhodopin, anhydrorhodovibrin, rhodo- 


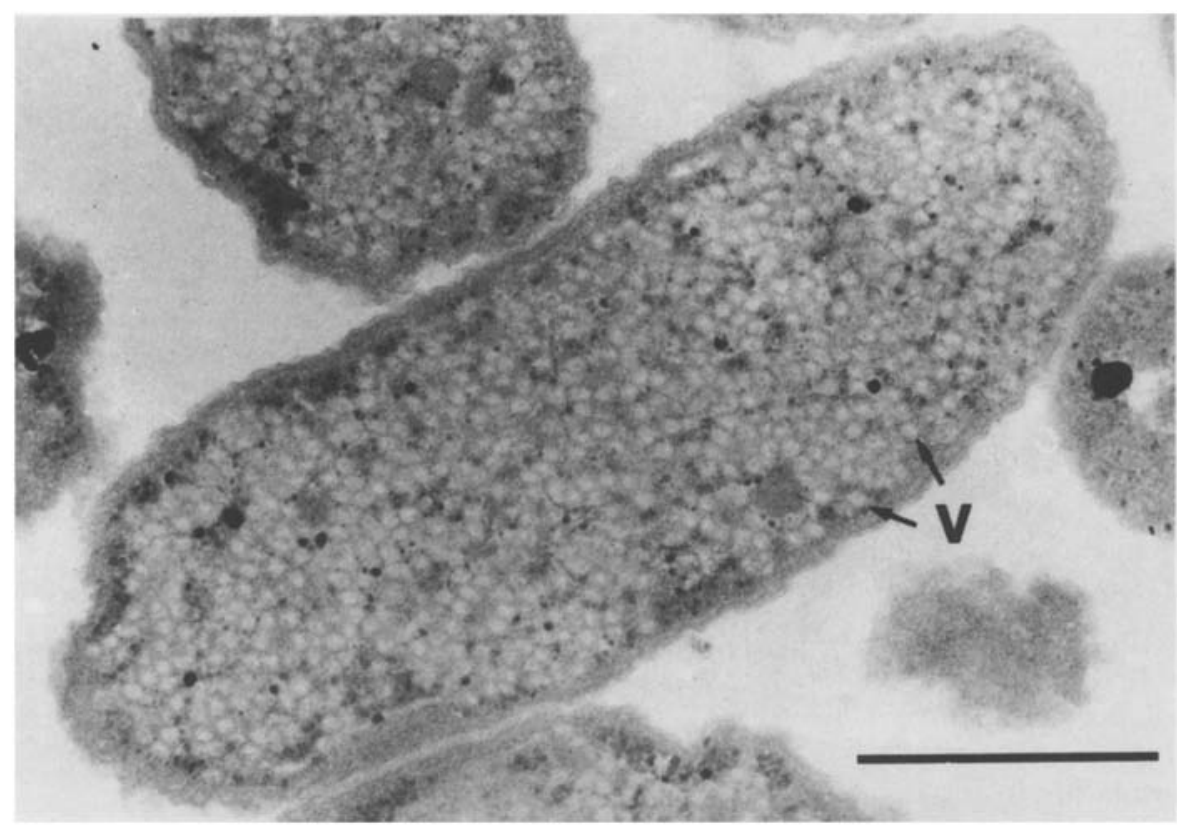

Fig. 4. Electron micrograph of ultrathin section of strain SSP1 showing the vesicular intracytoplasmatic membrane system. $v=$ vesicles. $B a r=0.5 \mu \mathrm{m}$

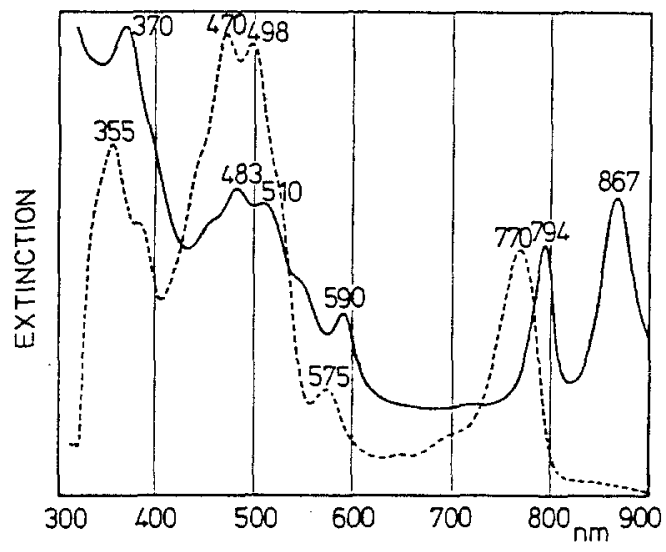

Fig. 5. Absorption spectra of strain SSP1. (-_ ) whole cells, $(---)$ acetone extract

vibrin and spirilloxanthin, were identified in different amounts in strain SSP1. Rhodopin was the main component. Rhodovibrin was not detected in strain 06511.

\section{Physiological properties}

Photolithoautotrophic growth occurred under anoxic conditions in the light with hydrogen sulfide, elemental sulfur (strain SSP1) and thiosulfate (strain 06511 only) as electron donors. Strain SSP1 was outstanding among all phototrophic sulfur bacteria examined so far in our laboratory with respect to its high growth rate and high cell yield reached during growth on elemental sulfur (sulfur flower).

In the presence of hydrogen sulfide and hydrogen carbonate, acetate, propionate and pyruvate were photoassimilated by strain SSP1.

Slightly increased cell yields of strain 06511 were obtained by addition of succinate, fumarate, malate, tartrate, malonate, glycerol, and peptone (Table 1).
With sulfide as electron donor, growth of strain SSP1 became light-saturated above light intensities of $50 \mu \mathrm{mol} \mathrm{m}{ }^{-2} \mathrm{~s}^{-1}$ (daylight fluorescent tubes, Osram daylight 5000 de luxe). No growth was obtained below $5 \mu \mathrm{mol} \mathrm{m} \mathrm{m}^{-2} \mathrm{~s}^{-1}$ even after an incubation period of six weeks.

Growth rates were maximal at $33{ }^{\circ} \mathrm{C}$. The optimum $\mathrm{NaCl}$ concentrations for growth of both strains were $2.2-3.2 \%(\mathrm{w} / \mathrm{v}, 340-520 \mathrm{mM})$. Significant growth of strain SSP1 was observed even at $7.2 \% \mathrm{NaCl}$.

Both strains did not require growth factors.

The maximum growth rate reached by strain SSP1 at $33^{\circ} \mathrm{C}$ and saturating light intensities was $2.0 \mathrm{~d}^{-1}$.

At saturating concentrations of hydrogen sulfide and oxygen $(10 \mu \mathrm{M}$ each), a maximal respiration rate of $264.2 \mathrm{nmol} \mathrm{O}_{2} \cdot(\mathrm{mg} \text { protein } \cdot \mathrm{min})^{-1}$ was determined in washed cell suspensions. Strain SSP1 grew chemotrophically in the dark. No photosynthetic pigments were detectable in chemotrophically grown cells.

The DNA base composition was $61 \pm 0.2$ and $62.4 \mathrm{~mol} \% \mathrm{G}+\mathrm{C}$ in strain SSP1 and 06511 , respectively.

\section{Discussion}

The surface of the Mahoney Lake littoral sediment colonized by Thiorhodovibrio winogradskyi is exposed to direct sunlight and atmospheric oxygen concentrations. The considerable amount of bacteriochlorophyll $a$ found at the sediment surface $\left(3.1 \mu \mathrm{g} \cdot \mathrm{cm}^{-3}\right.$ in the top $1 \mathrm{~cm}$ of the sediment) indicates that purple sulfur bacteria must be adapted to these environmental conditions.

The minimum light requirement of strain SSP1 for photosynthetic growth $\left(5 \mu \mathrm{mol} \mathrm{m}{ }^{-2} \mathrm{~s}^{-1}\right.$, daylight fluorescent tubes) is significantly higher than for all other isolates from the Mahoney Lake pelagial (0.4-1 $\mu \mathrm{mol} \mathrm{m} \mathrm{m}^{-2} \mathrm{~s}^{-1}$; Overmann et al. 1991). In contrast to pelagic habitats, light of longer wavelengths 
Table 1. Properties of Thiorhodovibrio winogradskyi strains SSP1 and 06511

\begin{tabular}{|c|c|c|}
\hline & SSP1 & 06511 \\
\hline \multicolumn{3}{|l|}{ Carbon sources utilized } \\
\hline Acetate (5) & + & + \\
\hline Propionate (1) & + & - \\
\hline Pyruvate (5) & + & + \\
\hline Succinate $(10)$ & - & $(+)$ \\
\hline Fumarate (5) & - & $(+)$ \\
\hline Malate (5) & - & $(+)$ \\
\hline Tartrate (2) & - & $(+)$ \\
\hline Malonate (5) & - & $(+)$ \\
\hline Glycerol (5) & - & $(+)$ \\
\hline Peptone $(0.025 \%)$ & - & $(+)$ \\
\hline \multicolumn{3}{|l|}{ Electron donors utilized } \\
\hline $\mathrm{H}_{2} \mathrm{~S}(1.25)$ & + & + \\
\hline $\mathrm{Na}_{2} \mathrm{~S}_{2} \mathrm{O}_{3}$ & - & + \\
\hline $\mathrm{S}_{8}$ & +++ & n. d. \\
\hline Cell morphology & $\begin{array}{l}\text { vibrio, } \\
\text { sometimes } \\
\text { spirilloid }\end{array}$ & $\begin{array}{l}\text { short } \\
\text { spirillum }\end{array}$ \\
\hline Cell length & $3.3 \pm 0.7 \mu \mathrm{m}$ & $3.2 \pm 0.7 \mu \mathrm{m}$ \\
\hline Cell width & $1.4 \pm 0.2 \mu \mathrm{m}$ & $0.8 \pm 0.1 \mu \mathrm{m}$ \\
\hline Flagellation & $\begin{array}{l}\text { monopolar } \\
\text { monotrichous }\end{array}$ & $\begin{array}{l}\text { monopolar } \\
\text { monotrichous }\end{array}$ \\
\hline $\begin{array}{l}\text { Intracytoplasmatic } \\
\text { membranes }\end{array}$ & vesicular & vesicular \\
\hline $\mathrm{mol} \% \mathrm{G}+\mathrm{C}$ of the DNA & $61 \pm 0.2$ & 62.4 \\
\hline \multicolumn{3}{|l|}{ Carotinoids ( $\%$ of total) } \\
\hline Lycopene & 6.4 & 14.9 \\
\hline Rhodopin & 47.4 & 55.3 \\
\hline Anhydrorhodovibrin & 13.6 & 10.2 \\
\hline Rhodovibrin & 4.1 & 0 \\
\hline Spirilloxanthin & 28.5 & 19.6 \\
\hline
\end{tabular}

Substrate concentrations in $\mathrm{mM}-=$ no utilization, $(+)=$ slightly stimulating growth, $+=$ growth, $+++=$ very high growth rate and cell yield, n.d. $=$ not determined. Substrates tested but not utilized (concentrations in $\mathrm{mM}$ ): glucose (5), fructose (5), mannitol (5), gluconate (5), L (+)-ascorbate (5), methanol (5), ethanol (5), propanol (5), butanol (5), ethylene glycol (5), 1,2-propanediol (5), 1,2-butanediol (5), 2,3-butanediol (5), formate (2.5), butyrate (2.5), valerate $(0.5)$, caproate $(0.5)$, caprylate $(0.5)$, crotonate $(0.2)$, lactate (10), glycollate (5), 2-oxoglutarate (5), citrate (2), acetoin (10), benzoate (2), trimethoxybenzoate $(2), \mathrm{L}(+)$-arginine $(5), \mathrm{L}(+)$ glutamate $(5)$, casamino acids $(0.1 \%)$, and yeast extract $(0.005 \%)$

penetrates the upper layers of sediments and reaches layers of purple sulfur bacteria (Jørgensen and Des Marais 1986). Using infrared light Thiorhodovibrio winogradskyi could be selectively enriched over other purple sulfur bacterial species present in the sediment (Amoebobacter purpureus, Chromatium vinosum). This indicates that light quality is one reason for the successful development of the new species in sediments and its absence at the chemocline of the pelagic region of the lake.

Thiorhodovibrio winogradskyi tolerates salt concentrations as high as $7.2 \% \mathrm{NaCl}$. In contrast, growth of Amoebobacter purpureus strains isolated from the Mahoney Lake pelagial was completely inhibited at $4.5 \% \mathrm{NaCl}$
(Overmann et al. 1991). Due to evaporation, the salt concentration in shore sediments of saline lakes is considerably higher than in the lake water itself. The growth optimum at $2.2-3.2 \% \mathrm{NaCl}$ of strains SSP1 and 06511 shows their specific adaptation to higher salt concentrations.

Abiotic oxidation of sulfide by oxygen results in the formation of polysulfides, elemental sulfur and thiosulfate (van Gemerden et al. 1989; Jørgensen and Bak 1991). In certain sediments, concentrations of polysulfides and elemental sulfur exceed those of thiosulfate (Luther et al. 1986; Visscher et al. 1990). The outstandingly high growth rates of Thiorhodovibrio winogradskyi with elemental sulfur point to a special adaptation to these environmental conditions.

Maximal oxygen uptake rates of Thiorhodovibrio winogradskyi strain SSP1 were five times higher in comparison to Chromatium vinosum $\mathrm{D}$ and Thiocystis violacea 2311 (Kämpf and Pfennig 1980). Comparable uptake rates were only reported for Thiocapsa roseopersicina M1 (de Wit and van Gemerden 1987), which also typically colonizes marine microbial mats. Due to the stagnation of oxygenic and anoxygenic photosynthesis at night, rapid diurnal changes occur in the vertical position of the redoxcline in sediments. Its motility enables Thiorhodovibrio winogradskyi to rapidly adjust its vertical position in the sediment to these changes.

Purple sulfur bacteria morphologically resembling Thiorhodovibrio winogradskyi were also observed in microbial mats of Great Sippewissett Salt Marsh (Cape Cod, Massachusetts, USA; N. Pfennig, personal observation). This species up to now has never been observed in lake water samples. Thiorhodovibrio winogradskyi obviously is widely distributed but appears to be restricted to hydrogen sulfide containing sediment layers within the photic zone of saline habitats. The present study shows that this species is well adapted to the environmental conditions prevailing in saline marine and lacustrine sediment systems.

Strain 06511 differed from strain SSP1 with respect to cell width and to organic carbon compounds utilized for phototrophic growth. All other properties examined compared well in both strains (Table 1).

The only genus of the Chromatiaceae resembling Thiorhodovibrio winogradskyi with respect to its vibroid to spirilloid morphology is Thiospirillum (Pfennig and Trüper 1989). Different features preclude an affiliation of the newly isolated strains to the genus Thiospirillum. The DNA base composition of the type strain Thiospirillum jenense is $45.5 \mathrm{~mol} \% \mathrm{G}+\mathrm{C}$ and thus by far lower than for strains 06511 and SSP1. Cells of $T$. jenense are considerably larger $(30-40 \mu \mathrm{m}$ long and $2.5-4 \mu \mathrm{m}$ wide) than the new strains and bear flagellar tufts. In contrast to Thiorhodovibrio winogradskyi, Thiospirillum jenense has so far been found only in freshwater habitats (Pfennig and Trüper 1989).

More than 100 years ago, the species Thiospirillum rosenbergii had been described by Warming in 1875 (Bavendamm 1924); this species has a similar shape as Thiorhodovibrio winogradskyi. However, Thiospirillum rosenbergii (length: $4-12 \mu \mathrm{m}$, width: $1.5-2.6 \mu \mathrm{m}$ ) is sig- 
nificantly greater than Thiorhodovibrio winogradskyi (Table 1), other characteristics are unknown.

The considerable phenetic differences of the newly isolated bacterium to all existing genera of the Chromatiaceae justify to consider the new bacterium as a new genus and species of the Chromatiaceae, Thiorhodovibrio winogradskyi; gen. nov. and sp. nov.

Thiorhodovibrio gen. nov.

Thi.o.rho.do.vi'brio. Gr. n. thios sulfur; Gr. n. rhodos the rose; 1 . v. vibro vibrate; M. L. masc. $n$. vibrio that which vibrates; Thiorhodovibrio rose vibrio with sulfur.

Individual cells are vibrioid- to spirilloid-shaped. Multiplication by binary fission; motile by means of a single polar flagellum. Gram-negative. Intracytoplasmatic membrane system of vesicular type. Photosynthetic pigments are bacteriochlorophyll a and carotenoids.

Phototrophic under anoxic conditions, may be facultatively chemotrophic at reduced oxygen partial pressure. Photolithoautotrophic growth with sulfide or sulfur as electron donor; during oxidation, globules of elemental sulfur are transiently stored inside the cells. Final oxidation product is sulfate. In the presence of sulfide organic substances may be photoassimilated.

Habitat: surface layers of marine and salt lake sediments and microbial mats containing hydrogen sulfide.

The $\mathrm{mol} \% \mathrm{G}+\mathrm{C}$ of the DNA is $61-63$ (HPLC).

Type species: Thiorhodovibrio winogradskyi sp. nov. Description of the type species Thiorhodovibrio winogradskyi sp. nov. wi.no.grad'sky.i. M. L. gen. n., named for S. N. Winogradsky, a Russian microbiologist, who did the first comprehensive studies on the purple sulfur bacteria.

Cells vibrioid- to spirilloid-shaped, $1.7-5.0 \mu \mathrm{m}$ long, $0.7-2.1 \mu \mathrm{m}$ wide. Anaerobically grown cultures are pink to light pinkish-purple. Living cell suspensions show absorption maxima at 370-372, 483-484, 510, 590-591, $794-795$ and $867 \mathrm{~nm}$. Photosynthetic pigments are bacteriochlorophyll $a$ and rhodopin as the main carotenoid component; further carotenoids are lycopene, anhydrorhodovibrin, rhodovibrin and spirilloxanthin.

Phototrophic under anoxic conditions, facultatively chemotrophic under mixotrophic conditions at reduced oxygen partial pressure $\left(1 \% \mathrm{O}_{2}\right)$. Photosynthetic electron donors used: sulfide, sulfur, and thiosulfate (used by some strains). High growth rates with elemental sulfur as electron donor. In the presence of sulfide and hydrogen carbonate, acetate and pyruvate are photoassimilated; in addition, some strains use propionate, succinate, fumarate, malate, tartrate, malonate, glycerol and peptone. When growing on sulfide or thiosulfate, up to ten small sulfur globules are formed inside the cell, often in a row along its long axis.

pH Range: $7.0-7.4$. Growth temperature: $14-37^{\circ} \mathrm{C}$, optimum temperature $33^{\circ} \mathrm{C}$. Optimum light intensity $50 \mu \mathrm{mol} \mathrm{m}{ }^{-2} \mathrm{~s}^{-1}$, minimum light requirement $5 \mu \mathrm{mol}$ $\mathrm{m}^{-2} \mathrm{~s}^{-1}$ (fluorescent light). Salinity range of growth: $0.2-7.2 \% \mathrm{NaCl}$, optimum salinity: $2.2-3.2 \%$. No vitamins required for growth.

Habitat: Strains were isolated from sulfide-containing surface layers of salt lake sediment and marine microbial mats.
61.0

The $\mathrm{mol} \% \mathrm{G}+\mathrm{C}$ of the DNA of the type strain is Type strain: DSM No 6702 (strain SSP1)

Acknowledgements. The investigations were partly supported by a travel grant from the Deutsche Forschungsgemeinschaft to the first author. We thank Dr. G. Sandmann, University of Konstanz, Konstanz, FRG, for help during the carotenoid determinations. The authors are indebted to Dr. Jahnke for the determination of the DNA base ratios.

\section{References}

Bavendamm W (1924) Die farblosen und roten Schwefelbakterien des Süß- und Salzwassers. Kollwitz R (ed): Pflanzenforschung Heft 2. Gustav Fischer, Jena

Cole RM, Popkin TJ (1981) Electron microscopy. In: Gerhardt P, Murray RGE, Costilow RN, Nester EW, Wood WA, Krieg NE, Phillips B (eds) Manual of methods for general bacteriology. American Society for Microbiology, Washington, pp $36-51$

De Wit R, Gemerden H van (1987) Chemolithotrophic growth of the purple sulfur bacterium Thiocapsa roseopersicina. FEMS Microbiol Ecol 45: 117-126

de Wit R, Gemerden H van (1989) Growth of the photoautotrophic purple sulfur bacterium Thiocapsa roseopersicina under oxic/ anoxic regimens in the light. FEMS Microbiol Ecol 73:69-76

Gemerden H van, Tughan CS, De Wit R, Herbert RA (1989) Laminated microbial ecosystems on sheltered beaches in Scapa Flow, Orkney Islands. FEMS Microbiol Ecol 62: 87-102

Goodwin TW (1980) The biochemistry of the carotenoids, vol 1. Plants, 2nd edn. Chapman and Hall, London New York, p 377

Hartree EF (1972) Determination of protein: a modification of the LOWRY-method that gives a linear photometric response. Anal Biochem 48: 422-427

Horridge GA, Tamm SL (1969) Critical point drying for scanning microscopic study of ciliary motion. Science 163: 817-818

Jørgensen BB, Des Marais DJ (1986) Competition for sulfides among colorless and purple sulfur bacteria in cyanobacterial mats. FEMS Microbiol Ecol 38: 179-186

Jørgensen BB, Bak F (1991) Pathways and sulfate reduction in a marine sediment (Kattegat, Denmark). Appl Environ Microbiol 57: 847-856

Kämpf C, Pfennig N (1980) Capacity of Chromatiaceae for chemotrophic growth. Specific respiration rates of Thiocystis violacea and Chromatium vinosum. Arch Microbiol 127: 125-135

Luther GW, Church TM, Sandlark JR, Cosman M (1986) Inorganic and organic sulfur cycling in salt-marsh pore waters. Science 232: 746-749

Meshbah M, Premachandrou U, Whitman W (1989) Precise measurement of the $\mathrm{G}+\mathrm{C}$ content of deoxyribonucleic acid by high performance liquid chromatography. Int J Syst Bacteriol 39: $159-167$

Nicholson JAM, Stolz JF, Pierson BK (1987) Structure of a microbial mat at Great Sippewisset Marsh, Cape Cod, Massachusetts. FEMS Microbiol Ecol 45: 343-364

Overmann J, Beatty JT, Hall KJ, Pfennig N, Northcote TG (1991) Characterization of a dense, purple sulfur bacterial layer in a meromictic salt lake. Limnol Oceanogr 36: 846-859

Parkin TB, Brock TD (1980) Photosynthetic bacterial production in lakes: The effects of light intensity. Limnol Oceanogr 25: $711-718$

Pfennig N (1978) Rhodocyclus purpureus gen. nov. and spec. nov., a ring-shaped, vitamin $B_{12}$-requiring member of the family Rhodospirillaceae. Int J Syst Bacteriol 28: 283-288

Pfennig N (1989) Ecology of phototrophic purple and green sulfur bacteria. In: Schlegel HG, Bowien B (eds) Autotrophic bacteria. Springer, Berlin Heidelberg New York, pp 97-116 
Pfennig N, Trüper HG (1981) Isolation of members of the families Chromatiaceae and Chlorobiaceae In: Starr HP, Stolp H, Trüper HG, Balows A, Schlegel HG (eds) The prokaryotes. A handbook on habitats, isolation and identification of bacteria. Springer, Berlin Heidelberg New York, pp 279-289

Pfennig N, Trüper HG (1989) Anoxygenic phototrophic bacteria In: Staley JT, Bryant MP, Pfennig N, Holt JG (eds) Bergey's manual of systematic bacteriology, vol. 3. Williams and Wilkins, Baltimore, pp 1635-1709

Reynolds E (1963) The use of lead citrate at high $\mathrm{pH}$ as an electron opaque stain in electron microscopy. J Cell Biol 17: 208-212.

Schmidt K (1978) Biosynthesis of carotenoids. In: Clayton RK, Sistrom WR (eds) The photosynthetic bacteria, Plenum Press, New York, pp 729-750

Siefert E, Pfennig N (1984) Convenient method to prepare neutral sulfide solution for cultivation of phototrophic sulfur bacteria. Arch Microbiol 139: 100-101

Steenbergen CLM, Korthals HJ (1982) Distribution of phototrophic microorganisms in the anaerobic and microaerophilic strata of Lake Vechten (The Netherlands). Pigment analysis and role in primary production. Limnol Oceanogr 27: 883-895

Takahashi M, Ichimura S (1968) Vertical distribution of organic matter production of photosynthetic sulfur bacteria in Japanese lakes. Limnol Oceanogr 13: 644-655

Trüper HG (1980) Distribution and activity of phototrophic bacteria at the marine water-sediment interface. In: Daumas R (ed) Biogéochimie de la matière organique à l'interface eau-sediment marin. Colloques Intern du CNRS (Paris) No 293, pp 275-282

Visscher PT, Nijburg JW, Gemerden H van (1990) Polysulfide utilization by Thiocapsa roseopersicina. Arch Microbiol 155: 75-81 